AperTO - Archivio Istituzionale Open Access dell'Università di Torino

\title{
Epiphytic lichen communities in chestnut stands in Central-North Italy
}

\section{This is the author's manuscript}

Original Citation:

Availability:

This version is available http://hdl.handle.net/2318/88616

since 2016-10-11T15:57:49Z

Published version:

DOI:10.2478/s11756-011-0145-8

Terms of use:

Open Access

Anyone can freely access the full text of works made available as "Open Access". Works made available under a Creative Commons license can be used according to the terms and conditions of said license. Use of all other works requires consent of the right holder (author or publisher) if not exempted from copyright protection by the applicable law. 
This is the author's final version of the contribution published as:

Enrica Matteucci; Renato Benesperi; Paolo Giordani; Rosanna Piervittori; Deborah Isocrono. Epiphytic lichen communities in chestnut stands in Central-North Italy. BIOLOGIA. 67 (1) pp: 61-70.

DOI: $10.2478 / \mathrm{s} 11756-011-0145-8$

The publisher's version is available at:

http://www.springerlink.com/index/pdf/10.2478/s11756-011-0145-8

When citing, please refer to the published version.

Link to this full text:

http://hdl.handle.net/2318/88616 


\title{
Epiphytic lichen communities in chestnut stands in Central-North Italy
}

\author{
Enrica Matteucci ${ }^{1} /$ Renato Benesperi $^{2} /$ Paolo Giordani $^{3}$ / Rosanna Piervittori ${ }^{4}$ / Deborah Isocrono ${ }^{1}$ \\ ${ }^{1}$ Dipartimento di Colture Arboree, University of Torino, Via Leonardo da Vinci, 44, I-10095, \\ Grugliasco, Italy
}

${ }^{2}$ Dipartimento di Biologia Evoluzionistica, University of Firenze, Via la Pira 4, I-50121, Firenze, Italy

${ }^{3}$ Botanic Centre Hanbury, DIP.TE.RIS., University of Genova, Corso Dogali 1M, I-16136, Genova, Italy

${ }^{4}$ Dipartimento di Biologia Vegetale, University of Torino, Viale Mattioli 25, I-10125, Torino, Italy

\begin{abstract}
Chestnut forest ecosystems represent an important component of the European Mediterranean basin and the Southern Alps landscape. Despite the good knowledge acquired in the phytosanitary and cultural aspects of chestnut, there is still a lack of data on the relationships between chestnut and epiphytes. We have investigated the changes in frequency of occurrence and species composition of lichen assemblages against the main site characteristics and environmental variables in chestnut woods along a bioclimatic and geographical gradient in Central-North Italy.
\end{abstract}

The study has highlighted a geographic gradient from the Western Alps to the Northern Apennines. We recorded a total of 152 taxa, only 49 of which occurring in all the bioclimatic zones. The distribution of lichen communities in chestnut stands is mainly associated with increasing precipitation and decreasing temperature, thus confirming the prevailing influence of macroclimatic factors on epiphytic lichens. The species composition statistically differs also in stands differently managed (orchards vs. coppices).

Chestnut woods host interesting communities, with rare species related to Lobarion, and can represent a good habitat for threatened epiphytic species.

Keywords: Castanea sativa; Lobaria; coppice; Lichen Diversity Value; orchard

\section{Introduction}

Epiphytic lichens have a high sensitivity to habitat modifications (Sillet \& Goslin 1999; Aude \& Poulsen 2000; Humphrey et al. 2002; Pykala 2004; Moning et al. 2009). In forest ecosystems epiphytic communities have been widely investigated considering the impact of forestry and the conservation policies (Ellis \& Coppins 2007; Perhans et al. 2007; Fritz et al. 2008; Lukošiene \& Naujalis 2009; Svoboda et al. 2010, 2011). The composition and species frequency in lichen communities are different in old-growth and second-growth forests, as has been demonstrated in Northern Europe and in the United States (Lesica et al. 1991; Esseen et al. 1996; Hilmo \& S`astad 2001; Boudreault et al. 2002; Radies \& Coxon 2004; Friedel et al. 2006; Mežaka et al. 2008). Some studies have also focused on the relationship between the climatic and environmental variables with the distribution and species richness of epiphytic lichens (Bergamini et al. 2007; Giordani 2007). Chestnut ecosystems represent an important landscape component of the European Mediterranean basin and the Southern Alps. Chestnut stands in Europe cover more than 18200 km2 (Amorini et al. 2000; data available 
for 10 countries); in Italy, chestnut stands cover over $7650 \mathrm{~km} 2,70 \%$ of which are actively managed (Conedera et al. 2004; Manetti et al. 2006).

Many different aspects have been investigated regarding chestnut woods: ranging from biological and botanical features, to cultivation techniques, pests and diseases, and economy (e.g. Leonardi et al. 2000; Bounous 2002; Bounous \& Beccaro 2010). Ecological researches have mainly been performed on vascular plants (Gondard \& Romane 2005; Gondard et al. 2006). Only a few studies have been related to cryptogams, such as epiphytic bryophytes (Privitera \& Puglisi 2000; Privitera et al. 2006) and fungi (Barluzzi et al. 1992; Diamandis \& Perlerou 2001; Venturella et al. 2006). Lichens have been rarely investigated in chestnut ecosystems (Lindacher \& Pietschmann 1990; Loppi et al. 1997; Loppi \& Nascimbene 1997; Roth \& Scheidegger 1997; Tretiach \& Ganis 1999) even though chestnuts can represent a suitable habitat for epiphytic lichen communities and also for threatened species, thanks to the chemical-physical characteristics of chestnut bark and to the micro-environmental conditions of the orchards (Scheidegger \& Clerc 2002; Benesperi \& Fappiano 2005).

The aim of this study was to investigate the changes in frequency of occurrence and species composition of lichen assemblages against the main environmental variables in chestnut woods along a climatic and geographical gradient in Italy. We therefore evaluated lichen diversity in different types of Castanea sativa dominated stands along the Northern Apennines and Western Alps.

\section{Material and methods}

Sampling design A total of 67 plots have been selected by means of a stratified random sampling. A first stratification has been carried out on the bioclimatic subdivision of the study area considering three bioclimatic regions defined following the phytoclimatic division of Italy (Ministero dell'Ambiente e Tutela del Territorio, 2005). Three categories were selected (Fig. 1): Temperate Semicontinental (TSC), Temperate Oceanic (TO), Mediterranean Oceanic (MO). Within each bioclimatic region two further stratifications have been performed based respectively on: - a geographic stratification, in order to cover homogeneously the geographic distribution of chestnut woods in the Western Alps and Northern Apennines in Italy. A total of 13 sites have been selected in the bioclimatic regions ( 6 in the Temperate Semicontinental, 6 in the Mediterranean Oceanic and 7 in the Temperate Oceanic). Sites were defined as geographic areas with a continuous distribution of chestnut woods, - a management stratification with two categories (orchard and coppice) proportional to the occurrence of the two management strategies within the bioclimatic regions leading on the whole to 30 plots in coppices and 37 in orchards (10 vs. 14 in the Temperate Semicontinental; 7 vs. 19 in the Temperate Oceanic and 13 vs. 4 in the Mediterranean Oceanic, respectively). Due to traditional land use, the management of the chestnut plantations within each site, was mostly uniform. When differing, a proportional selection of orchards vs. coppices plots were performed proportionally to the occurrence of the management also at site-level. In the field, a couple of the randomly selected coordinates were located and the plot was installed as the area within $10 \mathrm{~m}$ radius. The altitude of the plots ranges from 250 to $1060 \mathrm{~m}$ a.s.l. and the mean rainfall rates range from 653 to $2914 \mathrm{~mm} /$ year. The annual mean temperature varies from 8 to $14{ }^{\circ} \mathrm{C}$. All the chestnut trees in the plots were analyzed, for a total of 260 reléves carried out between 2003 and 2009. Environmental data were recorded at plot level (Table 1): temperature, rainfall rate, geographic coordinates, circumference at $120 \mathrm{~cm}$ above the ground of the analyzed trees. Two management categories were identified: chestnut orchard (grafted trees in open stands for fruit production) and coppice (chestnut forests regenerated for wood production). The frequency of occurrence of each lichen species was calculated for each tree using a sampling grid consisting of a $10 \times 50 \mathrm{~cm}$ ladder divided into 5 quadrats of $10 \times 10 \mathrm{~cm}$. The ladder grid was placed systematically on the N, E, S and W side of the bole with the top edge $1.5 \mathrm{~m}$ above the ground. We calculated the number of species per tree in the grid and the Lichen Diversity Value (LDV - Asta et al. 2002) as the sum of the frequency of each species within the sampling grids on a tree. The nomenclature of the taxa, autoecology and morphofunctional characters of species follows Nimis \& Martellos (2008).

Data processing

A One-way ANOVA at plot level was applied to test the hypothesis of equality of the epiphytic lichen diversity (number of species) and frequency of occurrence (LDV) means between the three bioclimatic zones. In order to detect the main lichen communities occurring in the chestnut stands, a "plot $x$ species presence" matrix was submitted to cluster analysis, using Jaccard as distance and Flexible Beta $(\beta=-0.25)$ as clustering algorithm. We used a global Non-metric multidimensional scaling (NMS) (Kruskal 1964) with the Sørensen distance, in order to detect the main gradients of variability of the lichen communities in the survey area. The analysis was performed with PC-ORD, version 4.25 (McCune \& Mefford 1999). The Pearson correlation of quantitative predictor environmental variables with ordination axes was used to interpret the relationships between these variables and the lichen community composition. 


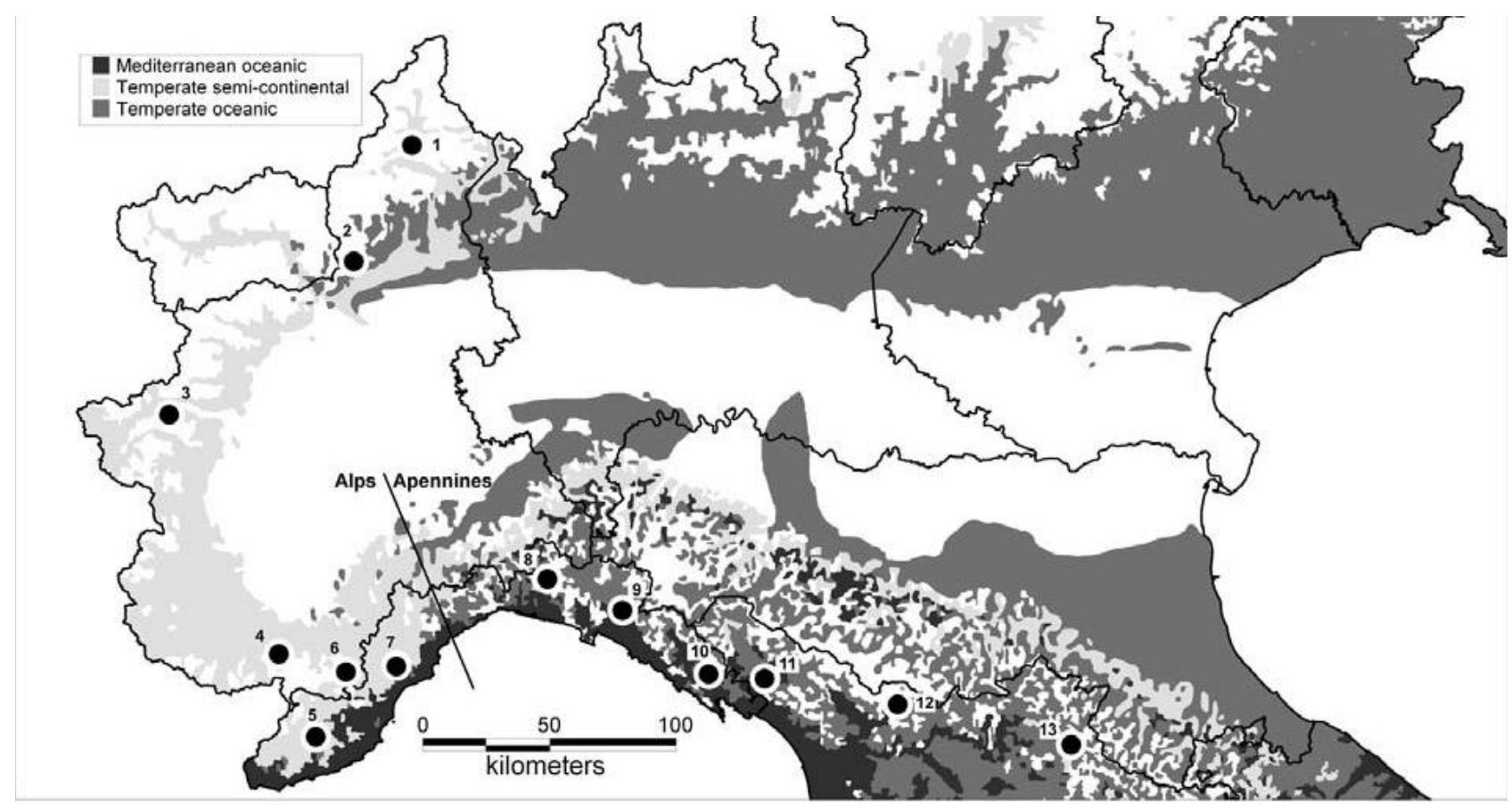

Fig. 1. Map of the study area showing the distribution of the three bioclimatic zones and the 13 investigated sites (1-7 sites in Western Alps, $8-13$ sites in Northern Apennines). 1 - Val Grande (VCO) 2 - Valle Cervo (BI) 3 - Valle di Susa (TO) 4 - Valle Germanasca (CN) 5 - Valle Argentina (IM) 6 Valle Tanaro (CN) 7 - Val Bormida (SV) 8 - Valle Scrivia (GE) 9 - Val d'Aveto (GE) 10 - Val di Vara (SP) 11 - Valle di Vinca (MS) 12 - Val di Lima (PT) 13 - Casentino (AR).

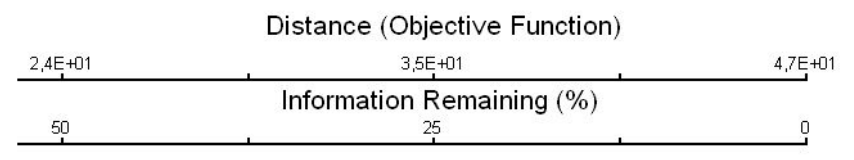

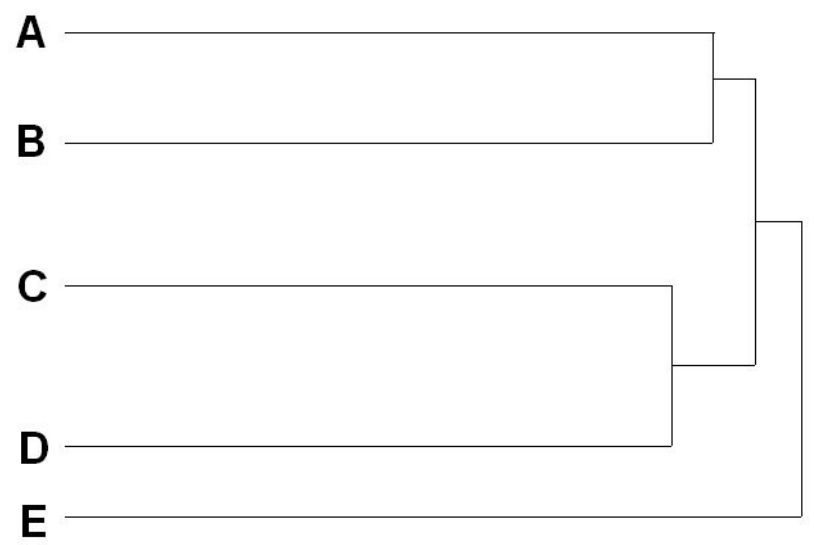

Fig. 2. Dendrogram (cluster analysis, Jaccard distance; Flexible Beta $=-0.25$ ) performed on the matrix 'species $\times$ plots' showing different types of vegetation (for single species within the clusters see Table 2).

\section{Results}

Frequency of occurrence and species diversity (ANOVA) A total of 152 taxa was recorded in 67 plots (Table 2), 49 taxa occurring in all the bioclimatic zones; whereas 24 taxa are exclusive to TSC, 24 to MO and 14 to TO. We found a statistically significant influence of bioclimatic zones on both the number of species and the LDV (Table 3). These latter were significantly lower in TSC than in TO. Lichen communities in MO cannot be distinguished on the basis of LDV and number of species. Lichen communities (cluster analysis) and environmental factors (NMS) In our study area five main lichen assemblages, ecologically well characterized, can be identified (Figs 2, 3). Cluster A (+) groups 19 taxa, $42 \%$ of which with Trentepohlia and $32 \%$ with Cyanobacteria as photosynthetic partner. This interesting assemblage with Degelia plumbea, Nephroma laevigatum, Pannaria conoplea (species 
characteristic of Lobarion community) was found on old trees in coppice stands in seminatural and humid habitats. Cluster B (_) groups 35 taxa mainly related to Lobarion community with Lobaria pulmonaria, L. amplissima, Lobarina scrobiculata, Nephroma parile and Peltigera collina as characteristic species. These communities are found on old trees in orchard stands, mainly in TO sites. Cluster $\mathrm{C}\left({ }^{\circ}\right)$ groups 43 taxa common throughout the study area, particularly in the oroboreal belt of the MO both in orchards and in coppices. Cluster $\mathrm{C}$ includes the succession from crustose communities developed on bark with intermediate roughness (e.g. Pertusaria spp. and Phlyctis spp.) to broad-lobed foliose Parmelion communities dominated by highly competitive species mainly characterized by vegetative reproductive strategies (e.g. Melanelixia spp. Parmelia spp.). Cluster D ( ) groups 17 taxa mainly nitrophilous and related to Xanthorion communitiy (e.g. Xanthoria spp., Candelaria concolor, Phaeophyscia orbicularis, Hyperphyscia adglutinata). These species are widespread in TSC zone. Cluster $\mathrm{E}(\cdot)$ groups 38 taxa and represents a constant assemblage of species occurring in all the study area. This assemblage can be referred to Parmelia and Pertusaria dominated communities (with Lecanora chlarotera, Lepraria incana, Normandina pulchella, Melanelixia fuliginosa, Parmelia saxatilis, P. sulcata, Pertusaria amara, P. flavida, Phlyctis argena) and it is a peculiar community of our chestnut stands when intermediate climatic and anthropogenicalteration conditions occur. We performed a NMS analysis on the entire dataset at plot level, comparing 1- to 6-dimensional solutions (Fig. 3). The best solution was a three-dimensional configuration (maximized difference between the best of 40 runs of real data and 50 randomized runs, $p<0.05$ from the Monte Carlo test; average stress $=17.5$ ). The cumulative Pearson $r$ between the distances in the original space and the distances on the three ordination axes was 0.702 . The axis with the highest $r_{2}(0.253)$ was labelled Axis 1 , followed by Axis 2 and Axis 3 ( $r_{2}=0.227$ and 0.223 , respectively). Epiphytic lichen diversity (number of species) and frequency of occurrence (LDV) showed a high positive correlation with Axis $1(\mathrm{r}=0.556$ and $\mathrm{r}=0.472$, respectively), according to gradients of increasing easting $(\mathrm{r}=0.747)$ and precipitation $(\mathrm{r}=0.568)$ and in contrast to a temperature gradient $(\mathrm{r}=-0.424)$. Axis 1 was also associated to the bioclimatic gradient: positively with TO $(r=0.564)$ and negatively with TSC $(r=-0.684)$. The influence of management is explained by Axis 2 , showing a contrasting gradient of orchards $(r=0.424)$ vs. coppices $(r=-0.425)$ also positively associated with circumference $(\mathrm{r}=0.488)$. Axis 3 (not shown) also described a negative gradient of diversity $(\mathrm{r}=-0.430$ for number of species and $r=-0.307$ for LDV) in relation to increasing temperature $(r=0.399)$. Several species, mainly belonging to Lobarion and Parmelion communities (e.g. Flavoparmelia caperata, Lobaria pulmonaria, Lobarina scrobiculata, Parmelia saxatilis, Parmelina pastillifera, P. tiliacea) and to Pertusaria genus, were strongly associated to positive values of Axis 1 (Table 2). Species growing on smooth bark (e.g. Arthopyrenia sp., Pyrenula sp., Graphis scripta) were associated to negative values of Axis 2 . Whereas species growing on acidic bark and decorticated trunks of old trees (e.g. Lepraria elobata, Hypocenomyce scalaris) were associated with positive values of the same axis.

\section{Discussion}

The diversity, frequency and composition of epiphytic lichen communities in Central-North Italy showed a geographic gradient from the Western Alps to the Northern Apennines. This continentality gradient recurs in the lichen distributional pattern in Italy, as was also observed for coniferous forests (Nascimbene et al. 2006). The distribution of lichen communities in chestnut stands is mainly associated to increasing precipitation and decreasing temperature (Fig. 3), thus confirming the prevailing influence of macroclimatic factors on epiphytic lichens (e.g. Ellis \& Coppins 2006, 2009, 2010; Giordani 2006; Giordani \& Incerti 2008; Nascimbene et al. 2010). As regards species composition, along the bioclimatic gradient, we observed a shift from xeric communities of Xanthorion, associated to TSC plots, to Lobarion and pre-Lobarion communities mainly found in $\mathrm{MO}$ and TO plots. Xanthorion communities are mainly associated to dry stands with high level of direct and indirect solar radiation; moreover they are favoured by relevant amount of atmospheric nitrogen depositions (Barkman 1958). Hence, in TSC chestnut stands they might occur both for natural climatic conditions and for anthropogenic alterations. Discerning the effect of pollution vs climate is out of the purpose of this study, but the low species diversity found in these plots and the comparison with previous floristic data of XIX century (e.g. Re 1824) may support the hypothesis of a drastic anthropogenic alteration of lichen communities in NW Alpine chestnut stands. Humid sites with intermediate species richness are characterized by Parmelion communities with Pertusaria spp. grouped in the cluster $E$. This species assemblage is one of the most common in temperate broadleaves forests in Italy (Castello \& Skert 2005). Chestnut orchards provide optimal conditions to these species thanks to the continuous canopy coverage which allows constant moderate solar direct radiation and high humidity rates at trunk level. Temperate oceanic plots, with high yearly precipitation rates, host species belonging to Lobarion communities. We mainly found them for positive values of Axis 2, corresponding to orchards stands characterized by the presence of old trees. This community represents one of the final successional stage of lichen colonisation in mature chestnuts so that it was used as indicator group of ecological continuity of the forest (Rose 1976). Moreover Lobaria pulmonaria has been recognized as an 
indicator for assessing forest sites worthy of conservation for lichens even in Italy (Nascimbene et al. 2010). According to "Ockinger et al. (2005) habitat qualities, features required for the persistence of the late successional species belonging to Lobarion communities, seems to be one of the most important factors for the colonisation success of the short distance dispersal lichen Lobaria pulmonaria. Moreover, the age structure of the forest also plays an important role: in disetaneous plots, the coexistence of trees of different ages and suckers assures the maintenance of the specific habitat qualities over the long term (Ohlson et al. 1997). Furthermore, early stage of pre-Lobarion communities (i.e. Nephrometum - cluster A) were found associated to managed coppice stands, in sites with lower humidity rates with respect to mature Lobarion communities. The occurrence of these lichen assemblages is related to the long-term turn coppicing, a management strategy less detrimental than short-rotation forestry. Some studies indicate that moderate disturbance is not damaging for these lichens (Esseen et al. 1992; Sillet et al. 2000) and mature thalli of L. pulmonaria respond positively to increased light availability (Coxon \& Stevenson 2007) which allowed the development of semi-mature communities. The complete succession to late stages was probably continuously interrupted allowing the occurrence, togheter with L. pulmonaria, of termophylous and eliophylous species (e.g. Fuscopannaria mediterranea, Nephroma laevigatum and Degelia plumbea). We showed that species richness and occurrence in chestnut stands are strictly associated with a decreasing gradient of continentality, whereas they are partially independent by the management. Nevertheless the species composition statistically differs for stands belonging to orchards and coppices (Fig. 3, Axis 2). This fact may be related to an uneven impact of management observed throughout the study area. In TO zone both orchards and disetaneous and/or old coppices may host rich communities where also rare species can occur (e.g. Nephrometum and Lobarion communities). This study fills a gap in the knowledge of chestnut ecosystem adding data about lichen communities at a medium-large investigation scale; it highligths continentality and short-term rotation as the main environmental and management influencing factors. 


\section{References:}

- [1] Amorini E., Chatziphilippidis G., Ciancio O., Di Castri F., Giudici F., Leonardi S., Manetti M.C., Nocentin S., Pividor M., Rapp M., Romane F., Sevrin E. \& Zingg A. 2000. Sustainability of chestnut forest ecosystems: is it possible? Ecol. Mediterr. 26: 3-14.

- [2] Asta J., Erhardt W., Ferretti M., Fornasier F., Kirschbaum U., Nimis P.L., Purvis O.W., Pirintsos S., Scheidegger C., Van Haluwyn C. \& Wirth V. 2002. Mapping lichen diversity as an indicator of environmental quality, pp. 273-279. In: Nimis P.L., Scheidegger C. \& Wolseley P. (eds), Monitoring with lichens - Monitoring lichens, Kluwer, Dordrecht. http://dx.doi.org/10.1007/978-94-010-0423-7_19

- [3] Aude E. \& Poulsen R.S. 2000. Influence of management on the species composition of epiphytic cryptogams in Danish Fagus forests. Appl. Veget. Sci. 3: 81-88. http://dx.doi.org/10.2307/1478921

- [4] Barkman J.J. 1958. Phytosociology and ecology of cryptogamic epiphytes. Van Gorcum and Comp., Assen, 628 pp.

- [5] Barluzzi C., Perini C. \& De Dominicis V. 1992. Coenological research on macrofungi in chestnut coppices of Tuscany. Phytocoenologia 20: 449-465.

- [6] Benesperi R. \& Fappiano A. 2005. Influenza della gestione forestale sulla distribuzione di Lobaria pulmonaria (L.) Hoffm. nell'Appennino settentrionale e Alpi Apuane (Toscana, Italia Centrale). Inform. Bot. Ital. 37: 392-393.

- [7] Bergamini A., Stofer S., Bollinger J. \& Scheidegger C. 2007. Evaluating macrolichens and environmental variables as predictors of the diversity of epiphytic microlichens. Lichenologist 39: 475-489. http://dx.doi.org/10.1017/S0024282907007074

- [8] Boudreault C., Gauthier S., Drapeau P. \& Bergeron Y. 2002. Bryophyte and lichen communities in mature to old-growth stands in eastern boreal forests of Canada. Can. J. Forest Res. 32: 1080-1093. http://dx.doi.org/10.1139/x02-027

- [9] Bounous G. 2002. Il castagno. Coltura, ambiente ed utilizzazioni in Italia e nel mondo. Bologna: Edagricole, $311 \mathrm{pp}$.

- [10] Bounous G. \& Beccaro G.L. 2010. Proceedings of the first European Congress on Chestnut Castanea 2009. Acta Horticulturae 1: 1-726.

- [11] Castello M. \& Skert N. 2005. Evaluation of lichen diversity as an indicator of environmental quality in the North Adriatic submediterranean region. Science of the Total Environment 336(1-3): 201-214. http://dx.doi.org/10.1016/j.scitotenv.2004.06.007

- [12] Conedera M., Manetti M.C., Giudici F. \& Amorini E. 2004. Distribution and economic potential of the sweet chestnut (Castanea sativa Mill.) in Europe. Ecol. Mediterr. 30: 179193.

- [13] Coxson D.S. \& Stevenson S.K. 2007. Influence of high-contrast and low-contrast forest edges on growth rates of Lobaria pulmonaria in the inland rainforest, British Columbia. Forest Ecol. Manag. 253(1-3): 103-111. http://dx.doi.org/10.1016/j.foreco.2007.07.008

- [14] Diamandis S. \& Perlerou C. 2001. The mycoflora of the chestnut ecosystems in Greece. For. Snow Landsc. Res. 76: 499-504.

- [15] Ellis C.J. \& Coppins B.J. 2006. Contrasting functional traits maintain lichen epiphyte diversity in response to climate and autogenic succession. J. Biogeography 33: 1643-1656. http://dx.doi.org/10.1111/j.1365-2699.2006.01522.x

- [16] Ellis C.J. \& Coppins B.J. 2007. Changing climate and historicwoodland structure interact to control species diversity of the 'Lobarion' epiphyte community in Scotland. J. Veget. Sci. 18(5): 725-734. http://dx.doi.org/10.1111/j.1654-1103.2007.tb02587.x

- [17] Ellis C.J. \& Coppins B.J. 2009. Quantifying the role of multiple landscape-scale drivers controlling epiphyte composition and richness in a conservation priority habitat (juniper scrub). Biol Conservation 142: 1291-1301. http://dx.doi.org/10.1016/j.biocon.2009.01.036 
- [18] Ellis C.J. \& Coppins B.J. 2010. Integrating multiple landscapescale drivers in the lichen epiphyte response: climatic setting, pollution regime and woodland spatial-temporal structure. Diversity and Distributions 16: 43-52. http://dx.doi.org/10.1111/j.1472-4642.2009.00624.x

- [19] Esseen P.A., Ehnstrom B., Ericson L. \& Sjoberg K. 1992. Boreal forests - the focal habitats of Fennoscandia, pp. 252-325. In: Hansson L. (ed.), Ecological Principles of Nature Conservation. Applications in Temperate and Boreal Environments, Elsevier Applied Science, London.

- [20] Esseen P.A., Renhorn K.E. \& Pettersson R.B. 1996. Epiphytic lichen biomass in managed and old-growth boreal forests: effect of branch quality. Ecological Applications 6: 228-238. http://dx.doi.org/10.2307/2269566

- [21] Friedel A., Oheimb G.V., Dengler J. \& Hardtle W. 2006. Species diversity and species composition of epiphytic bryophytes and lichens - a comparison of managed and unmanaged beech forests in NE Germany. Feddes Repert. 117: 172-185. http://dx.doi.org/10.1002/fedr.200511084

- [22] Fritz O., Gustafsson L. \& Krister Larsson K. 2008. Does forest continuity matter in conservation? - A study of epiphytic lichens and bryophytes in beech forests of southern Sweden. Biol. Conserv. 141: 655-668. http://dx.doi.org/10.1016/j.biocon.2007.12.006

- [23] Giordani P. 2006. Variables influencing the distribution of epiphytic lichens in heterogeneous areas: A case study for Liguria, NW Italy. Journal of Vegetation Science 17: 195-206. http://dx.doi.org/10.1111/j.1654-1103.2006.tb02438.x

- [24] Giordani P. 2007. Is the diversity of epiphytic lichens a reliable indicator of air pollution? A case study from Italy. Environ. Poll. 146: 317-323. http://dx.doi.org/10.1016/j.envpol.2006.03.030

- [25] Giordani P. \& Incerti G. 2008. The influence of climate on the distribution of lichens: a case study in a borderline area (Liguria, NW Italy). Plant Ecology 195: 257-272. http://dx.doi.org/10.1007/s11258-007-9324-7

- [26] Gondard H. \& Romane F. 2005. Long-term evolution of understorey plant species composition after logging in chestnut coppice stands (Cevennes Mountains, Southern France). Ann. Forest Sci. 62: 333-342. http://dx.doi.org/10.1051/forest:2005028

- [27] Gondard H., Romane F., Santa Regina I. \& Leonardi S. 2006. Forest management and plant species diversity in chestnut stands of three Mediterranean areas. Biodivers. Conservat. 15: 1129-1142. http://dx.doi.org/10.1007/s 10531-004-3103-8

- [28] Hilmo O. \& Såstad S.M. 2001. Colonization of old-forest lichens in a young and an old boreal Picea abies forest: an experimental approach. Biol. Conservation 102: 251-259. http://dx.doi.org/10.1016/S0006-3207(01)00100-8

- [29] Humphrey J.W., Davey S., Peace A.J., Ferris R. \& Harding K. 2002. Lichens and bryophyte communities of planted and semi-natural forests in Britain: the influence of site type, stand structure and deawood. Biol. Conservation 107: 165-180. http://dx.doi.org/10.1016/S0006-3207(02)00057-5

- [30] Kruskal J.B. 1964. Nonmetric multidimensional scaling: a numerical method. Psychometrika 29: 115-129. http://dx.doi.org/10.1007/BF02289694

- [31] Leonardi S., Rapp M. \& Romane F. 2000. Sustainability of chestnut forest ecosystems: is it possible? International Symposium organised by the Università degli Studi di Catania; 1998 Sep 18-23; Catania. Ecol. Mediterr. 26: 1-179.

- [32] Lesica P., McCune B., Cooper S.V. \& Hong W.S. 1991. Differences in lichen and bryophyte communities between oldgrowth and managed second-growth forests in the Swan Valley, Montana. Can. J. Bot. 69: 1745-1755. http://dx.doi.org/10.1139/b91-222 [CrossRef]

- [33] Lindacher R. \& Pietschmann M. 1990. Altersstadien moosreicher Vegetation auf Castanea sativa in Elba. Herzogia 8: 383-401. 
- [34] Loppi S. \& Nascimbene J. 1997. Lichen bioindication of air quality in the Mt. Amiata geothermal area (Central Italy). Geothermics 27: 295-304. http://dx.doi.org/10.1016/S03756505(98)00003-0

- [35] Loppi S., Putortì E. \& De Dominicis V. 1997. Florula lichenica epifita di un castagneto (Montieri, Toscana). Atti del Museo di Storia Naturale della Maremma 16: 85-90.

- [36] Lukošiene I.P. \& Naujalis J.R. 2009. Rare lichen associations on common oak (Quercus robur) in Lithuania. Biologia 64: 48-52. http://dx.doi.org/10.2478/s11756-009-0004-z

- [37] Manetti M.C., Amorini E. \& Becagli C. 2006. New silvicultural models to improve functionality of chestnut stands. Adv. Hort. Sci. 20: 65-69.

- [38] McCune B. \& Mefford M.J. 1999. Multivariate analysis of ecological data. Version 4.25. MjM Software, Gleneden Beach, OR, US.

- [39] Mežaka A., Brumelis G. \& Piterans A. 2008. The distribution of epiphytic bryophyte and lichen species in relation to phorophyte characters in Latvian natural old-growth broad leaved forests. Folia Cryptog. Estonica 44: 89-99.

- [40] Ministero dell'Ambiente e Tutela del Territorio, Politecnico di Torino. 2005. GIS Natura, il GIS delle conoscenze naturalistiche in Italia.

- [41] Moning C., Werth S., Dziock F., Bässler C., Bradtka J., Hothorn T. \& Müller J. 2009. Lichen diversity in temperate montane forests is influenced by forest structure more than climate. Forest Ecol. Manage. 258: 745-751. http://dx.doi.org/10.1016/j.foreco.2009.05.015

- [42] Nascimbene J., Isocrono D., Marini L., Caniglia G. \& Piervittori R. 2006. Epiphytic lichen vegetation on Larix in the Italian Alps. Plant Biosystems 140: 132-137. http://dx.doi.org/10.1080/11263500600756264

- [43] Nascimbene J., Brunialti G., Ravera S., Frati L. \& Caniglia G. 2010. Testing Lobaria pulmonaria (L.) Hoffm. as an indicator of lichen conservation importance of Italian forests. Ecological Indicators 10: 353-360. http://dx.doi.org/10.1016/j.ecolind.2009.06.013

- [44] Nimis P.L. \& Martellos S. 2008. ITALIC - The Information System on Italian Lichens. Version 4.0. University of Trieste, Dept. of Biology, IN4.0/.1. Available from: http://dbiodbs.univ.trieste.it/.

- [45] Öckinger E., Niklasson M. \& Nilsson S. 2005. Is local distribution of the epiphytic lichen Lobaria pulmonaria limited by dispersal capacity or habitat quality? Biodivers. Conserv. 14: 759-773.

- [46] Ohlson M., Söderström L., Hörnberg G., Zakckrisson O. \& Hermansson J. 1997. Habitat qualities versus long-term continuity as determinants of biodiversity in boreal old-growth swamp forests. Biol. Conserv. 81: 221-231. http://dx.doi.org/10.1016/S0006-3207(97)000013

- [47] Perhans K., Gustafsson L., Jonsson F., Nordin U. \& Weibull H. 2007. Bryophytes and lichens in different types of forest setasides in boreal Sweden. Forest Ecol. Manage. 242: 374390. http://dx.doi.org/10.1016/j.foreco.2007.01.055

- [48] Privitera M. \& Puglisi M. 2000. The ecology of bryophytes in the chestnut forests of mount Etna (Sicily, Italy). Ecol. Mediterr. 26: 43-52.

- [49] Privitera M., Puglisi M., Cenci R.M. \& Beone G.M. 2006. Bryophytes biodiversity for monitoring chestnut ecosystem on Mount Etna (Estern Sicily). Adv. Hort. Sci. 20: 28-32.

- [50] Pykala J. 2004. Effects of new forestry practices on rare epiphytic macrolichens. Conservation Biol. 18: 831-838. http://dx.doi.org/10.1111/j.1523-1739.2004.00210.x

- [51] Radies D.N. \& Coxon D.S. 2004. Macrolichen colonization on 120-140 year old Tsuga heterophylla in wet temperate rainforests of central-interior British Columbia: a comparison of lichen response to even-aged versus old-growth stand structures. Lichenologist 36: 235247. http://dx.doi.org/10.1017/S0024282904014227

- [52] Re G.F. 1824. Flora pedemontana. Appendix altera. Tip. Regia Taurini. 
- [53] Rose F. 1976. Lichenological indicators of age and environment continuity in woodlands, pp. 279-307. In: Brown D.H., Hawksworth D.L. \& Bailey R.H. (eds), Lichenology: Progress and Problems Academic Press, London.

- [54] Roth I. \& Scheidegger C. 1997. Die Edelkastanie als Lebensraum für epiphytische Flechten. Bünderwald 3: 59-68.

- [55] Scheidegger C. \& Clerc P. 2002. Lista Rossa delle specie minacciate in Svizzera: licheni epifiti e terricoli. Ed. Ufficio Federale dell'Ambiente, Foreste e Paesaggio UFAFP, Berna, Istituto federale di ricerca WSL, Birmensdorf, Conservatoire et Jardin botaniques de la Ville de Genčve CJBG L'ambiente in pratica, UFAFP Serie.

- [56] Sillett S.C. \& Goslin M.N. 1999. Distribution of epiphytic macrolichens in relation to remnant trees in a multiple-age Douglas-fir forest. Can. J. For. Res. 29: 1204-1215. http://dx.doi.org/10.1139/x99-081

- [57] Sillett S.C., McCune B., Peck J.E., Rambo T.R. \& Ruchty A. 2000. Dispersal limitations of epiphytic lichens result in species dependent on old-growth forests. Ecol. Appl. 10: 789799. http://dx.doi.org/10.1890/1051-0761(2000)010[0789:DLOELR]2.0.CO;2

- [58] Svoboda D., Peksa O. \& Vesela J. 2010. Epiphytic lichen diversity in central European oak forests: assessment of the effects of natural environmental factors and human influences. Env. Poll. 158: 812-819. http://dx.doi.org/10.1016/j.envpol.2009.10.001

- [59] Svoboda D., Peksa O. \& Veselá J. 2011. The analysis of epiphytic lichen composition in Central European oak forests. Preslia 83: 129-144.

- [60] Tretiach M. \& Ganis P. 1999. Hydrogen sulphide and epiphytic lichen vegetation: a case study on Mt. Amiata (Central Italy). Lichenologist 31: 163-181. http://dx.doi.org/10.1006/lich.1998.0173

- [61] Venturella G., Saita A. \& Pecorella E. 2006. Fungal biodiversity in chesnut woods of Sicily (Southern Italy). Adv. Hort. Sci. 20: 28-23. 